basis metals. One of the great strengths of the Association is the opportunity which its structure provides of bringing metallurgical researches on widely different materials to a common basis, where the information obtained in one investigation can be applied with advantage in another. While the annual report describes the work in progress classified according to the particular sections of the industry interested in specific items, work in the laboratories is more easily described under the headings of the separate sections of the Research Department.

In the Melting and Casting Section, the accommodation of which is now being increased, some aspects of the metal/gas reactions causing unsoundness in castings, which have been studied intensively by the Association for many years, are still under investigation. 'The bulk of work at present, however, is concerned with fundamental investigations of $(a)$ the mechanism of grain refinement in castings ; and (b) the thermal gradients existing in castings during solidification and the effect thereon both of the metal or alloy itself and of the mould material.

The Mechanical Testing Section has now extensive equipment for the investigation of creep and fatigue of metals at room and elevated temperatures. The studies of creep resistance form a large part of the work of this Section, the programme ranging from lead and lead alloys (mainly at room temperature) to high-conductivity coppers at temperatures up to about $200^{\circ}$ C., aluminium alloys, and more recently to copper alloys at temperatures up to $500^{\circ} \mathrm{C}$. While much of this work has specific objects, various sections of the investigation are planned on fundamental lines, and the maximum opportunity is being taken for providing basic information on the mechanism of creep in these different materials.

A great deal of the work of the Physies Section is service work (particularly in spectrographic analysis and X-ray crystal analysis) for the other sections of the Research Department, but research is also in progress on the improvement of the spectrographic method, on the technique and utility of the electron microscope and on the fundamentals of soft-soldering operations. Researches in the Corrosion Section are mainly concerned with improving resistance to corrosion of copper, aluminium, zinc and their alloys by sea water and by domestic waters. Stress corrosion, particularly from the point of view of elucidating the fundamental mechanism of stress corrosion attack, is also being studied in aluminium and copper alloys. The General Metallurgy Section is dealing with a range of problems such as hot working, recrystallization and oxidation, and includes in its programme some exploratory investigations on the properties of titanium alloys at moderately high temperatures. Finally, a newly equipped Metal Finishing Section is now well under way with studies of the mechanism of adhesion of electrodeposits on aluminium and of the electropolishing of non-ferrous metals and alloys generally.

The annual report also includes paragraphs on the Information and Liaison Departments, lists of the reports issued during the year and of the officers, council and committees of the Association. It is interesting to note that more than two hundred representatives of industry co-operate through the various research committees and thus ensure that members of the staff are not without the support of that technological and practical experience which they themselves are necessarily in some cases lacking.

\section{BRITISH BAKING INDUSTRIES RESEARCH ASSOCIATION} NEW RESEARCH STATION I

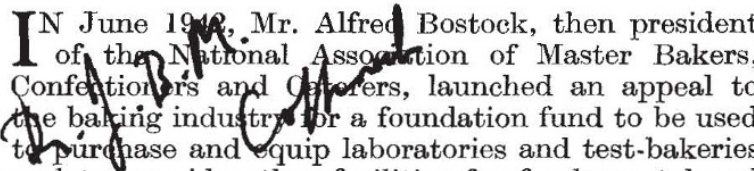
and to provide other facilities for fundamental and ad hoc research into the problems of the industry. In June 1943, a trade conference, at which all sections of the baking industry were represented, set up a committee under the chairmanship of Prof. H. D. Kay, director of the National Institute for Research in Dairying. The committee entered into direct negotiation with the Department of Scientific and Industrial Research, and, with its guidance and help, the British Baking Industries Research Association was incorporated under the Companies Act on June 13, 1946. This committee acted as an interim council of the new Association until September 1946, when the first council was elected and began to enrol additional members. As soon as the Association was established as a legal entity, Prof. Kay relinquished the chairmanship, remaining an additional member of council, and Dr. R. T. Colgate was elected to succeed him.

On March 13, 1947, the council appointed Dr. J. B. M. Coppock as director of research, and he took up his duties on May 1 in that year. Later in the year, Chorleywood Lodge, a country house in Chorleywood, Herts, was bought, and its conversion to a research station began immediately. The equipping and staffing of the laboratories was carried out in stages, approximately six weeks being taken to equip each one. The first to be completed was the analytical laboratory, and immediately an advice service to members on the composition of raw materials became available. All possible accommodation in Chorleywood Lodge has now been converted, the last laboratory to be completed being the biochemical one. During the past eighteen months, fundamental research has been started on such problems as the cause and control of bread-staling, the physical properties of bread and biscuit doughs and cake batters, high-frequency baking and its potential applications, and many aspects of panary fermentation. Research reports which have been published include "Mineral Oils in Bread" and "The Determination of Extraneous Materials in Biscuits". Other publications sent to members include Baking Abstracts, published monthly in two sections, Science and General, and a bi-monthly Bulletin, which gives in semi-technical language interim results of work carried out at the Research Station, general surveys of advances in the science, technology and practice of baking, etc. Plans have now been approved for a new wing which will house a pilot-scale bakery, a nutrition laboratory and animal house and cereal laboratories.

The Research Station was formally opened by H.R.H. the Duchess of Kent on June 28. At this ceremony, the Lord President of the Council, Mr. Herbert Morrison, promised the continued financial support of the Department of Scientific and Industrial Research, provided that the industry also continues to play its part. At present, a grant of $£ 9,500$ in this financial year has been made by the 
Department, as a result of the industry having contributed $£ 18,500$ in membership subscriptions.

During her tour of inspection after the opening ceremony, the Duchess of Kent, accompanied by Mr. Morrison, was shown displays of some of the work that is being carried out. The synthesis of chemically pure polyoxyethylene monostearate was demonstrated in the organic research laboratory. This substance has been marketed in an impure form in the United States and is under consideration in Britain as a 'crumb-softener'. The object of incorporating such a substance, as its name suggests, is to delay crumbhardening, which is one of the most apparent manifestations of bread-staling. Its effect, when incorporated into a bread dough, was illustrated by loaves of various ages. It was pointed out that toxicological tests are also in progress, and members of the industry have been advised not to use polyoxyethylene monostearate or similar substances until considerably more information has been obtained on their possible physiological effects. The use of organo-silicon polymers to produce water-repellent surfaces on bread tins, to which dough will not adhere, the storage of biscuits under tropical conditions, the importance of personal hygiene and the ways in which salmonella and staphylococcal food-poisoning arise through carelessness on the part of operatives, were also illustrated.

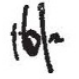

\section{FORTHCOMING EVENTS}

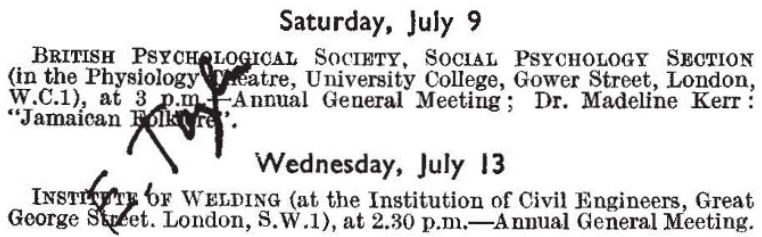

Thursday, July 14-Saturday, July 16

Physicat Socrety (in the Radiophysics Section of the Cavendish Laboratory, Cambridge).-Conference on "The Ionosphere and the Propagation of Radio Waves".

Friday, July 15-Saturday, July 16

British RHEOLOGISTS' CLUB (joint meeting with the MIdLAND CHEMISTs, at the University, Edgbaston, Birmingham).-Conference on "The Rheology of Thickened Liquids".

\section{APPOINTMENTS VACANT}

APPIICATIONS are invited for the following appointments on or before the dates mentioned :

ASSISTANT I TOTURER IN THE DEPARTMENT OF INORGANIC AND PHYSICAL COMISTRY - The Registrar, The University, Liverpool

LECT 15 (rade II) IN PHYSIOLOGY-The Secretary and Registrar, The Universit? Bristol (July 15)

LFETURER IN STATISTIOS in the Department of Mathematics in the Uni College-The Secretary, The University, St. Andrews (July 15).

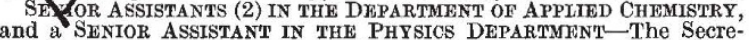
and a SENIOR ASSISTAN' IN THE PHPSICs DEPARTMNnT-The Secre16).

LEOTURFRs (3) IN MATHAMamucs for classes to General B.Se. standard and/or Higher National Certificate in Engineering (Mechanical and Electrical), and a LECTURFR IN PHYsICs to teach classes up to General B.Sc. standard-The Clerk to the Governors, Luton and South Bedfordshire College of Further Education, Education Office, Town Hall, Luton, Beds (July 16).

TESTING OFFICER and an EQUIPMENT ENGINEER, in the Dairy Engineering Department-The Secretary, National Institute for Research in Dairying, Shinfield, Reading, Berks (July 16).

ScIENCE OFFIOERS, to serve overseas or in specialist departments of the London headquarters - The Director, Personnel Department, British Council, 3 Hanover Street, London, W.1, endorsed 'Science Officer' (July 16).
LeCTURER IN Mathematics at the Coventry Technical CollegeThe Director of Education, Council House, Coventry (July 16). LECTURER IN THE DEPARTMENT OF BOTANY-The Secretary, Edin burgh and East of Scotland College of Agriculture, 13 George Square, Edinburgh 8 (July 16).

PHYsICIST to the Radiotherapy Department-The House Governor St. Mary's Hospital, Paddington, London, W.2 (July 18).

SENIOR RESEAROH FELIOWSHIP for research into some aspects of University or Training College education-The Registrar, The University, Leeds 2 (July 18)

E.E.R. RECORDIST (female) IN THE DEPARTMENT OF APPLIn] ELECTROPHYSIOLOGY - The Secretary, Institute of Psychiatry, Maudsley Hospital, Denmark Hill, London, S.E.5 (July 23).

CHAIR OF ECONOMICS in the University of Cape Town-The Secre tary, Association of Universities of the British Commonwealth, Gordon Square, London, W.C.1 (July 25).

ASSISTANT ADVISORY OFHICER IN AGRICULTURAL BOTANY, and an ASSistant ADVISORY OFFICER IN AgricUlTuRAL ENTOMOLOGY-The Secretary, Edinburgh and East of Scotland College of Agriculture, 13 George Square, Edinburgh 8 (July 27).

I.C.I. FALLOWSHIP for research in Chemistry or Physies or a related subject at Durham or Newcastle-The Registrar, University Office, 46 North Bailey, Durham (July 30).

LECTURER IN AGRIOULTURAL ECONOMICS, and a LECTURER IN AGRICUTTURAL ZOOLOGY-The Secretary, The University, Aberdeen (July 30 ).

ASsistant Lectorer in The Department of Botany-The Registrar, The University, Liverpool (July 30).

LECTURER IN CIVIL ENGINEERING in the subject of Fluid Mechanics and Hydraulics-The Head of the Department of Civil Engineering, City and Guilds College, South Kensington, London, S.W.7

GEOLOGIST in the Public Service, and FORESTERS (2) in the Forestry Department of the Department of Agriculture and Lands, Governfor Southern Rhodesia, Rhodesia House, 429 Strand, London, W.C.2 (August 4).

GRADUATE BIOCHEMIST to teach Microbiology, Chemistry and Physics in relation to food-The Secretary, Smithfleld College of Food Technology, Eagle Court, St. John's Lane, London, E.C.1 (August 6) TEACHER OF ScIENCE (preferably a graduate in Physics or Chemistry -The Secretary, L.C.C. London School of Printing, 61 Stamford treet, London, S.E.1 (August 13).

LECTURER IN INORGANIC AND PHYSICAL CHEMISTRY in the University of Western Australia- The Agent-General for Western Australia ayoy House, 115-116 Strand, London, W.C.2 (August 22).

Professor OF PHYSICS, a LeCTURER IN PSYCHOLOGY, a Professoh OF FTNE ARTS, and a LECTURER IN ECONOMIC HISTORY, at Rhodes University College, Grahamstown, South Africa-The Secretary, Association of Universities of the British Commonwealth, 5 Gordon Square, London, W.C.1 (August 31).

LECTURER IN TAXONOMY in the Department of Botany-The Secretary, University College, Gower Street, London, W.C.1 (September 15).

Metallurgists, Physical Chrmists and Physicists in investigator and research assistant posts, and a METALLURGIST in the Liaison Department for work in the application of research results to industrial practice-The Secretary, British Non-Ferrous Metals Research Association, 81-91 Euston Street, London, N.W.1.

RESEARCH BURSARY (tenable in the Department of Fuel Technology, The University, Sheffield) for research into fundamental or applied heat transfer in furnaces-The Personnel Officer, British Iron and Steel Research Association, 11 Park Lane, London, W.1, endorsed 'Plant Engineering Division'.

LECTURER IN EIECTRIOAL ENGINEERING, and a LEOTURFR IN Physics-The Principal, North Staffordshire Technical College, Stoke-on-Trent.

SCIENTIFIC OFTICERS (Entomologists) in the International Red Locust Control Service, Abercorn, Northern Rhodesia-The Secretary, Anti-Locust Research Centre, British Museum (Natural History), Cromwell Road, London, S.W.7.

MEN interested in the technological application of fundamental research results on natural rubber and in the development of new processes-The Director of Research, British Rubber Producers' Research Association, 48 Tewin Road, Welwyn Garden City, Herts. Research Association, 48 Tewin Road, Welwyn Garden City, Herts.
LECTURER IN THE DEPARTMENT OF MATHEMATICS-The Principal, LECTURER IN THE DEPARTMENT OF MATHEMATICS-The
Northampton Polytechnic, St. John Street, London, E.C.1.

ASTSTANT LECTURER IN CHEMISTRY, and a LECTURER (resident) is
ASTIST ASSISTANT LECTURER IN CHEMISTRY, and a LECTURER (resident) IN
AGRICULTURAI BAOTERIOLOGY-The Bursar, Seale-Hayne AgriAGRICULTURAI BAOTERIOLOGY - The
cultural College, Newton Abbot, Devon.

OFWOER IN CHARGE, GENERAL AGRICULTURAL ANAIJYSIS SECTION of the East African Agriculture and Forestry Research OrganisationThe Under-Secretary of State, Colonial Office, Research Department, The Under-Secretary of State, Colonial Office, Research Depar

anctuary Buildings, Great Smith Street, London, S.W. 1 . for investigations in connexion with the reclamation, drainage and for investigations in connexion with the reclamation, drainage and ment, Colonial Office, Sanctuary Buildings, Great Smith Street, London, S.W.1.

London, S.W.1. ASSISTANT BACTERIOLOGIST-The Secretary, University
Hospital Medical School, University Street, London, W.C.1.

LECTURER IN MATHEMatics, and a LECTURER IN CHEMistryThe Principal, Sir John Cass Technical Institute, Jewry Street, London, E.C.3.

PHYSICIST to undertake research work into dust sampling instruments and the physical properties of airborne dusts, especially in coal-mining-The Director, Pneumokoniosis Research Unit, Llandough Hospital, Penarth, Glam.

TRCHNICAL ASSISTANT to be responsible for the physico-chemical research laboratories - The Head of the Chemistry Department, King's College, Strand, London, W.C.2.

SENIOR PHYSICIST to take charge of researches on the physical aspects of rubber science and technology, and a GRADUATE CHEMIST (woman) for abstracting and other work on technical literatureThe Secretary, Research Association of British Rubber Manufacturers, 105 Lansdowne Road, Croydon, Surrey. 